\title{
Shock heterogeneity and shock history of the recently found ordinary Csátalja chondrite in Hungary
}

\author{
Akos KERESZTURI ${ }^{1, *}$, Krisztian FINTOR ${ }^{2}$, Ildiko GYOLLAI ${ }^{3}$, Zsolt KERESZTY ${ }^{4}$, Mate SZABO ${ }^{3}$, \\ Zoltan SZALAI ${ }^{5,6}$ and Helena WALTER ${ }^{2}$
}

1 Research Centre for Astronomy and Earth Sciences, Konkoly Thege Miklos Astronomical Institute, H-1121 Budapest, Konkoly Thege Miklós út 15-17, Hungary

2 University of Szeged, Vulcano Petrology and Geochemistry Research Group, Department of Mineralogy, Geochemistry and Petrology, Hungary

3 Research Centre for Astronomy and Earth Sciences, Institute for Geological and Geochemical Research, Hungary

4 International Meteorite Collectors Association (IMCA\#6251)

5 Research Centre for Astronomy and Earth Sciences, Geographical Institute, Hungary

6 Eötvös Loránd University, Department of Environmental and Landscape Geography, Hungary

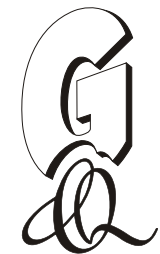

\begin{abstract}
Kereszturi, A., Fintor, K., Gyollai, L., Kereszty, Z., Szabo, M., Szalai, Z., Walter, H., 2018. Shock heterogeneity and shock history of the recently found ordinary Csátalja chondrite in Hungary. Geological Quarterly, 62 (2): 433-446, doi: $10.7306 / g q .1416$

Shock impact-produced mineral alterations in two thin sections of the recently found Csátalja $\mathrm{H} 4$ ordinary chondrite meteorite are compared. Peak positions of Raman and infrared spectra of mineral clasts show peaks shifted in wavenumber relative to unshocked reference minerals, and both peak shifts and FWHM values seem to correlate to each other. In the less shocked thin section (Csátalja-1) a more monomineralic and homogeneous composition indicate shock pressures of $<15 \mathrm{GPa}$, while the more shocked Csátalja-2 indicates shock pressure in the 15-17 GPa range. The highest identified infrared peak position shifts range between -48 and $+28 \mathrm{~cm}^{-1}$ with peak broadening between $60-84 \mathrm{~cm}^{-1}$ in the case of the feldspars, which, together with sulphide globules, were produced by the shock itself. Feldspar spectra could be detected only by FTIR spectroscopy, but in most cases (above the S3 shock level) the mixed type of the pyroxene-feldspar spectra (both peaks in the same spectra) is in agreement with the shock-produced secondary feldspars. These grains are located around crystalline borders, and probably formed by selective melting, due to shock annealing. In reconstruction of the shock history, an early fragmentation by a lower shock effect and a later increased shock level-related vein and melt pocket formation occurred, with subsequent shock annealing; temporal reconstruction of the shock event is possible only in part. The joint usage of Raman and infrared spectroscopy provided useful insights into the shock-produced changes and their spatial inhomogeneity, while shocked feldspar could be better detected by infrared than by the Raman method.
\end{abstract}

Key words: meteorite, shock impact alteration, ordinary chondrite, infrared and Raman spectroscopy.

\section{INTRODUCTION}

FTIR ATR (Fourier Transform Infrared spectrometer with Attenuated Total Reflection objective) based mineral analysis is becoming popular as such equipment is more readily available. Although in classical Earth sciences this method is already used, for cosmic materials it has been less commonly employed. In this work we analyse typical meteorite minerals, including shock-altered ones, in order to demonstrate some useful capabilities of FTIR ATR and also the limits of this method,

\footnotetext{
* Corresponding author, e-mail: kereszturi.akos@csfk.mta.hu
}

Received: August 18, 2017; accepted: January 26, 2018; first published online: May 17, 2018 by comparing infrared observations with better established Raman measurements for phase identification and characterization (Fintor et al., 2014). The aim besides the methodological testing is to characterize the shock deformation and estimate formation conditions, the extent of small-scale heterogeneity, and to reconstruct a shock history of this meteorite. This analysis provides information on early melting (Krzesińska, 2016), thermal metamorphism (Borucki and Stępniewski, 2001) and complex mineral formation history (Pilski et al., 2001) including the reconstruction of the parent body's structure (Borucki et al., 2009) and age estimation of various geological events (Hałas and Wójtowicz, 2001).

The first specific aim of this work is to gain insight into the characteristics of the shock-driven alteration of a recently found meteorite. A secondary aim is to gain new experiences on methodological aspects, using both Raman and infrared ATR based data, as the later one is poorly standardized with few results obtained from meteorite minerals. By the joint application 
of Raman and infrared methods, shock levels and related peak pressure and temperature values could be estimated in the same meteorite sample by these different methods to help understand the complex processes that acted on the meteorite parent bodies (Tyburczy et al., 1986; Przylibski et al., 2003; Beck et al., 2005). The target object: Csátalja is a H4, S2 W2 chondrite meteorite, which was found in 2012 in Hungary, and based on the differences between its different parts, is probably a breccia. The meteorite shows high iron abundance (25-31\%), its main minerals are: orthopyroxene, olivine (fayalite content $16-20 \mathrm{~mol} \%$ ), $15-19 \%$ reduced $\mathrm{Ni}-\mathrm{Fe}$ metal and $5 \%$ troilite. These minerals are partly metamorphosed to petrographic grade 3-7 (usually 5).

Earlier results on the usage of IR ATR are summarized below. The first study of the FTIR ATR method was by Müller et al. (2004), who measured minerals in sedimentary rocks such as feldspar, quartz, carbonates, and clay minerals. Detailed studies of clay minerals were obtained by Madejová and Komadel (2001), Madejová (2003), Udvardi et al. (2014) and Kovacs et al. (2015a). FTIR ATR was used in archaeological science to measured pure mineral powders such as cosmetics, pigments and ceramics (De Benedetto et al., 2002; Doménech-Carbó et al., 2012). A comparative study of infrared spectroscopic methods was made by Lane et al. (2011), including FTIR ATR methods. Previously ATR was also used to provide standard band positions to estimate interstellar dust composition (Morlok et al., 2006), and for shock analysis of Martian meteorites (Koizumi et al., 2010), to identify metasomatic alteration of meteorite olivine (Kereszturi et al., 2015). In the analysis of shock alteration of impact target rocks on the Earth (Basavaiah et al., 2013) applied aspects of ATR based IR spectroscopy were summarized by Reach et al. (2012).

\section{METHODS}

Target areas of the thin sections were first identified and roughly characterized by optical methods, then analysed by Raman and finally by FTIR ATR methods. A polarizing microscope Eclipse E600 POL was used for textural analysis and basic mineral determination. Shock stages were also initially estimated by optical microscopy using the Stöffler scale. Olivines with mosaic structure are classified as S3-S4 (mainly in the Csátalja-1 sample shock vein, see below), while shock-annealed and subgrained mixed composition mineral clasts are classified as S5 shock stage (see below: Csátalja-1 and -2 samples), and the shock melt, occurring as a pocket (mainly in Csátalja-2), formed at the S6 shock stage. In this work we analyse and compare these mineral alteration types.

\section{FTIR ATR METHOD}

For infrared spectroscopy and microscopy, a Vertex 70 FTIR spectrometer and Hyperion 2000 microscope were used with Attenuated Total Reflectance (ATR) objective (Johnston and Premachandra, 2001; Morlok et al., 2004; Chemtob et al., 2010; Słaby et al., 2016), where a high refractive index crystal was in physical contact with the target (Ohta and Iwamoto, $1985 a$, b). The infrared wave penetrates only a few micrometres below the surface as an evanescent wave and rapidly decays from the interface. The reflected beam is attenuated with corresponding frequencies to the vibration mode and overtones of the sample crystals (Ferguson, 2010). During the infrared analysis the minerals in the thin section were contacted by the tip of the germanium $(\mathrm{Ge})$ crystal of $100 \mu \mathrm{m}$ total diameter. All measurements were performed for $30 \mathrm{sec}$ at $4 \mathrm{~cm}^{-1}$ spectral and $10 \mu \mathrm{m}$ spatial resolution. Bruker Optics' Opus 5.5. software was used for manipulation of the resultant spectra (e.g., baseline correction, atmospheric compensation etc.).

\section{RAMAN ANALYSIS}

Phase analytical measurements were made by a THERMO Scientific DXR confocal Raman microscope (532 nm laser, $10 \mathrm{~mW}$ laser power, $100 \mathrm{X}$ objective lens, $25 \mu \mathrm{m}$ pinhole confocal aperture) in the laboratory of the Department of Mineralogy, Geochemistry and Petrology, University of Szeged. The focal point diameter was $\sim 1 \mu \mathrm{m}$, the spatial resolution some $\mu \mathrm{m}^{3}$ and the spectral resolution $2 \mathrm{~cm}^{-1}$. In the case of olivine, the end member spectra fitted the actual spectrum, based on the RRUFF database (Downs, 2006). For all of the olivine points, the spectrum of the forsterite matched the best, the fayalitedid not appear in the sample. According to the Foster et al (2013) diagram, which shows the peak positions of forsterite, these olivine points may fall approximately into the $\mathrm{Fo}_{80}$ range. The peak positions of minerals measured in our samples were compared to unshocked Earth-based mineral standards of similar chemistry; artificial shocked samples were also used. The feldspar spectra (oligoclase-labradorite) were compared to those of Freeman et al. (2008), the pyroxenes to Huang et al. (2000), and the olivines to Kuebler et al. (2006). The FWHM values (measured manually in Crystal Sleuth as the width at the half of the maximum peak intensity) were used to improve shock stage identification; using the crystalline lattice disordering they produce what could be identified in peak changes, and the values were compared to Rull et al. (2010) for pyroxenes and olivines, and to Fritz et al (2005) in the case of feldspars.

For the interpretation of shock-produced changes in the spectra, publications-based references of FWHM values were compared to the Raman spectroscopic and FTIR measurements realized in our work. The references used are from artificially produced pressure-driven laboratory-based deformation tests, so the FWHM values are definitely from pressure-driven crystalline lattice deformation. The unshocked olivines are characterized by main doublet peak positions of 820 and $850 \mathrm{~cm}^{-1}$ (Rull et al., 2010), with FWHM of $10 \mathrm{~cm}^{-1}$ (Miyamoto and Ohsumi, 1995). According to Miyamoto and Ohsumi (1995), the shocked olivine with $21 \mathrm{~cm}^{-1} \mathrm{FWHM}$ points to a shock stage of $15 \mathrm{GPa}, 900^{\circ} \mathrm{C}$. The existence of shock-related alteration beyond any solely temperature-produced FWHM change was confirmed by the peak position shift accompanied with an FWHM increase (see values in Tables 1 and 2). Beside these aspects, optical analysis showed mosaic structure and isotropic patches in these grains. This observation might support that FWHM increased not only because of elevated temperature.

\section{EMPA ANALYSIS}

Elemental composition of certain units of the sample was determined at 1-2 $\mu \mathrm{m}$ spatial resolution with EMPA on the sample covered in a vacuum-deposited thin amorphous carbon layer, using a JEOL Superprobe 733 electron microprobe with an INCA Energy 200 Oxford Instrument Energy Dispersive Spectrometer. The analytical circumstances were $20 \mathrm{keV}$ acceleration voltage, $6 \mathrm{nA}$ beam current and count time of $60 \mathrm{~s}$ for the spot measurement and 5 min for line scan analysis. Olivine, albite, plagioclase and wollastonite were standards; the detection limit estimated for main element identification was $<0.5 \%$ based on experience of earlier measurements with various samples. 
Ta ble 1

FTIR and Raman parameters of the minerals measured and the estimated expected shock stage of Csátalja-1 sample

\begin{tabular}{|l|c|c|c|c|c|c|}
\hline \multicolumn{1}{|c|}{ Mineral } & Optical shock level in Csátalja-1 & $\begin{array}{c}\text { Raman shock } \\
\text { induced shift in } \\
\text { Csátalja-1 }\end{array}$ & $\begin{array}{c}\text { Raman FWHM } \\
\text { is Csátalja-1 }\end{array}$ & $\begin{array}{c}\text { IR shock in- } \\
\text { duced shift in } \\
\text { Csátalja-1 }\end{array}$ & $\begin{array}{c}\text { IR FWHM in } \\
\text { Csátalja-1 }\end{array}$ & $\begin{array}{c}\text { Number of } \\
\text { measuring } \\
\text { points }\end{array}$ \\
\hline olivine & S4 (mosaicism) & 2 & $151-7$ & $-2-+5$ & 18 & 4 \\
\hline pyroxene & $\begin{array}{c}\text { S5 (shock annealed clast } \\
\text { resorbed rim subgrained } \\
\text { structure) }\end{array}$ & $1-4$ & 13 & $1-5-+16$ & $37-66$ & 6 \\
\hline pyroxene & $\begin{array}{c}\text { S3 (fractured } \\
\text { chondrule fragment) }\end{array}$ & $-5-10$ & $16-30$ & $-16-+4$ & $35-41$ & 3 \\
\hline pyroxene & S6 (mixed mineral melt) & $1-4$ & 12 & $5-14$ & 33 & 6 \\
\hline feldspar & only in mixed mineral melt (S6) & +1 & 18 & -10 & 70 & 5 \\
\hline
\end{tabular}

Table 2

FTIR and Raman parameters of the minerals measured and the estimated expected shock stage of Csátalja-2 sample

\begin{tabular}{|l|c|c|c|c|c|c|}
\hline \multicolumn{1}{|c|}{ Mineral } & Optical shock level in Csátalja-2 & $\begin{array}{c}\text { Raman shock } \\
\text { induced shift in } \\
\text { Csátalja-2 }\end{array}$ & $\begin{array}{c}\text { Raman FWHM } \\
\text { is Csátalja-2 }\end{array}$ & $\begin{array}{c}\text { IR shock in- } \\
\text { duced shift in } \\
\text { Csátalja-2 }\end{array}$ & $\begin{array}{c}\text { IR FWHM in } \\
\text { Csátalja-2 }\end{array}$ & $\begin{array}{c}\text { Number of } \\
\text { measuring } \\
\text { points }\end{array}$ \\
\hline olivine & S4 (mosaicism) & 2 & $16-18$ & $3-2$ & $11-26$ & 4 \\
\hline pyroxene & $\begin{array}{c}\text { S5 (shock annealed clast } \\
\text { resorbed rim subgrained } \\
\text { structure })\end{array}$ & 9 & 15 & $11-12$ & $31-39$ & 8 \\
\hline pyroxene & $\begin{array}{c}\text { S3 ( fractured } \\
\text { chondrule fragment) }\end{array}$ & 5 & 16 & 8 & 43 & 1 \\
\hline feldspar & only in mixed mineral melt (S6) & $-1-0$ & 14 & $19-32$ & $60-84$ & 5 \\
\hline
\end{tabular}

In general the FWHM (characterizing the regularity of the crystalline structure) and peak position shift (characterizing the crystalline domain size) together provide insight into the shock-caused alteration: while the increase in FWHM values might be caused both by shock driven elevated pressure and temperature or by only elevated temperature alone; however, the occurrence of increased FWHM values together with the peak position shift demonstrate that deformation of the crystalline lattice (changing the lattice parameter of the domain size) happened together with a decrease of the crystallinity level in general - while the thermal effect alone could increase only the FWHM and not produce a peak position shift. The joint use of peak positions and FWHM values analysis with both the Raman and infrared methods supports the better estimation of shock conditions.

\section{RESULTS}

The Csátalja-1 and Csátalja-2 samples were studied with a focus on shock alteration. Following the Stöffler et al. (1991) classification, various areas with different shock stages could be separated

- S3: emergence of fractured mineral/chondrule clasts (these are characteristic for higher shock stages too, at $70 \%$ of the brecciated, chondrule-rich part of the thin section area);

- S4: olivine showing mosaic extinction (10\% in Csátalja-2 - melt pocket, vicinity of melt pocket, shock veins; $23 \%$ in Csátalja-2 - shock veins and their vicinity);
- S5: subgrained clasts with selective melting (pyroxenes $-10 \%$ in shock melt pocket in Csátalja-2);

- S6: totally shock-melted rock $(7 \%$, Csátalja-1 - melt fraction in branching shock vein, $10 \%$ in Csátalja-2 melt pockets).

An overview of these location types with different optically based shock stages are shown in Figure 1. The Csátalja-1 sample contains clastic shock veins with mixed mineral clasts suggesting selective melting, with grains of mosaic extinction and fractured chondrules in the wall of the shock veins (Fig. 1). The Csátalja-2 contains a melt pocket with subgrained pyroxene, mixed casts showing selective melting (Fig. 2C, D) and shock veins (Fig. 2E, F).

During the analysis, altogether 23 measurements of the same point on the thin section with good IR and Raman data together were analysed, among them 8 were clean phases (in these cases both IR and Raman methods identified only one mineral type, characteristically around the $S 3$ shock stage and not above), while 15 locations showed mixed phases (usually around S5). Below we analyse and identify minerals using Raman and infrared spectroscopic methods (based on characteristic peak positions) and their basic spectral characteristics, then we provide the full width at half maximum (FWHM) values to see possible IR-Raman correlation with crystalline structural changes. The characteristics of clean and mixed phases are described in detail in the next section.

Figure 2 shows example spectra for the observed minerals modified by shock metamorphism according to the following parts of the image (sample identifier and mineral identifier are indicated in brackets): 

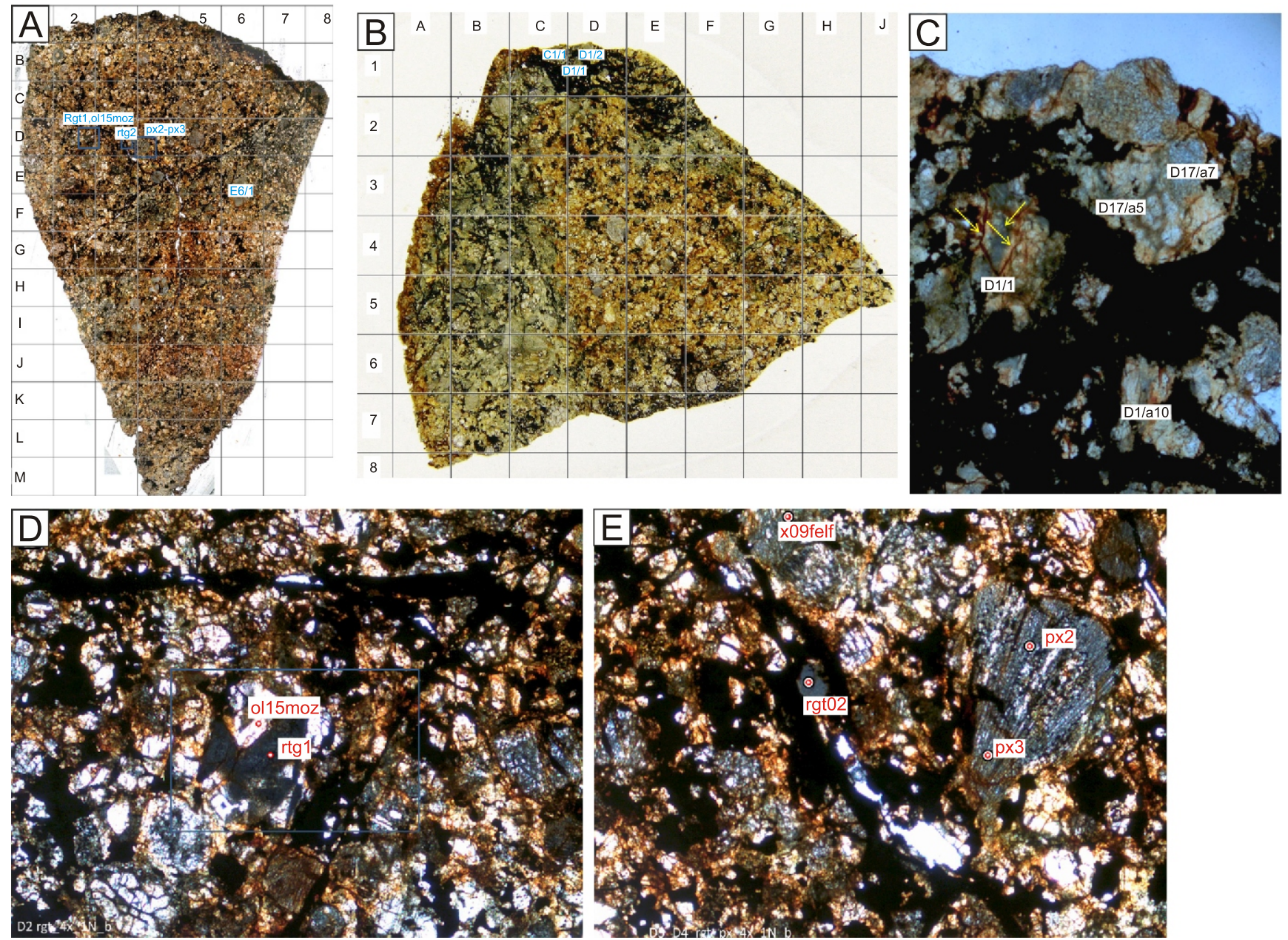

Fig. 1. Optical microscope images from the measured areas of the Csátalja-1 and -2 samples in transmitted light

A, B - map of thin sections of the Csátalja-1 (A) and of Csatalja-2 (B) samples, the measured points of the Csatalja-1 were taken from a shock vein, the measured points of the Csátalja-2 sample were taken from a melt pocket; $\mathbf{C}$ - measuring points of Csátalja-2 sample with mixed clasts around subgrain boundaries and fractures; D, E - measured points of the Csátalja-1 samples (D - rgt1 IR3, ol15moz IR4, E - D3 rgt2/3-4, px3a-c)

- A, B - weakly shocked, mosaic olivine (Csátalja-1, D2ol15mozIR4, A - FTIR, B - Raman),

- CD - weakly shocked, subgrained pyroxene lacking the signature of selective melting (Csátalja-2, D17a, C FTIR, D - Raman),

- E, F - strongly shocked pyroxene in melt pocket (Csátalja-2, D11IR3, E - FTIR, F - Raman),

- G, H-strongly shocked mixed mineral clast of pyroxene and feldspar around fractures and subgrain boundaries (Csátalja-2, D1a10IR4, G - FTIR, H - Raman),

- I, J - strongly shocked mixed mineral clast of pyroxene and feldspar in melt (Csátalja-2, D1a10IR3, I - FTIR (only feldspar), J - Raman),

- K, L - strongly shocked mixed mineral clast with much feldspar melt (Csátalja-2, D15IR3, K - FTIR, L Raman).

The measuring points were selected to be representative of the general appearance of the samples analysed, covering the range of differently shock-altered units. The Csátalja- 1 thin section contains clastic shock veins with a small amount of melt, whereas the Csátalja-2 thin section sample contains melt pockets with mixed clasts (pyroxene clasts with feldspar melt along the fractures and subgrain boundaries). The measuring points in the Csátalja-1 sample were selected in shock veins and taken of magnetite (E61), shocked pyroxenes (D2 rgt1, ol15moz, D3 px3) in shock vein (with mosaic structure and isotropic patches - Fig. 3C), whereas the Csátalja-2 sample in a shock melt pocket of feldspar melt and fewer clinopyroxenes (augite, diopside) with selective melting, feldspar-pyroxene mixtures (D1a5, D1a10 IR2, IR4; D11 IR1, IR2, IR3, IR5, IR6), less olivine (D1a10 IR1, D11-IR4), and pyroxene (D1a10 IR3, D17a7) were measured (Fig. 3G). These targets were selected as characteristic units of the thin section.

The same "pure" minerals were detected with both Raman and FTIR spectroscopy at only a few points of the Csátalja-1 (E61 - magnetite, D2 ol15 moz IR4 - forsterite) and Csátalja-2 samples (D1a10 IR1 - forsterite, IR3 - enstatite, D1a7 - enstatite, altogether in 7 cases out of 25). Most of the spectra (Csátalja-1 -60\%, Csátalja-2 - 70\%) are a mixture of the minerals noted above, while a pure feldspar spectrum was detected only by infrared spectroscopy. The identification of pure versus mixed phases is influenced by the spatial resolution differences of Raman and FTIR-ATR microscope objectives: while FTIR microscope works with with a $20 x$ objective $(340 \mu \mathrm{m}$ diameter field view area of the sample with spatial resolution of 2-4 $\mu \mathrm{m}$ ), the Raman measurements were taken under 100x magnification objective $(140 \mu \mathrm{m}$ diameter field of view area on the sample) with spatial resolution of $1 \mu \mathrm{m}$. 

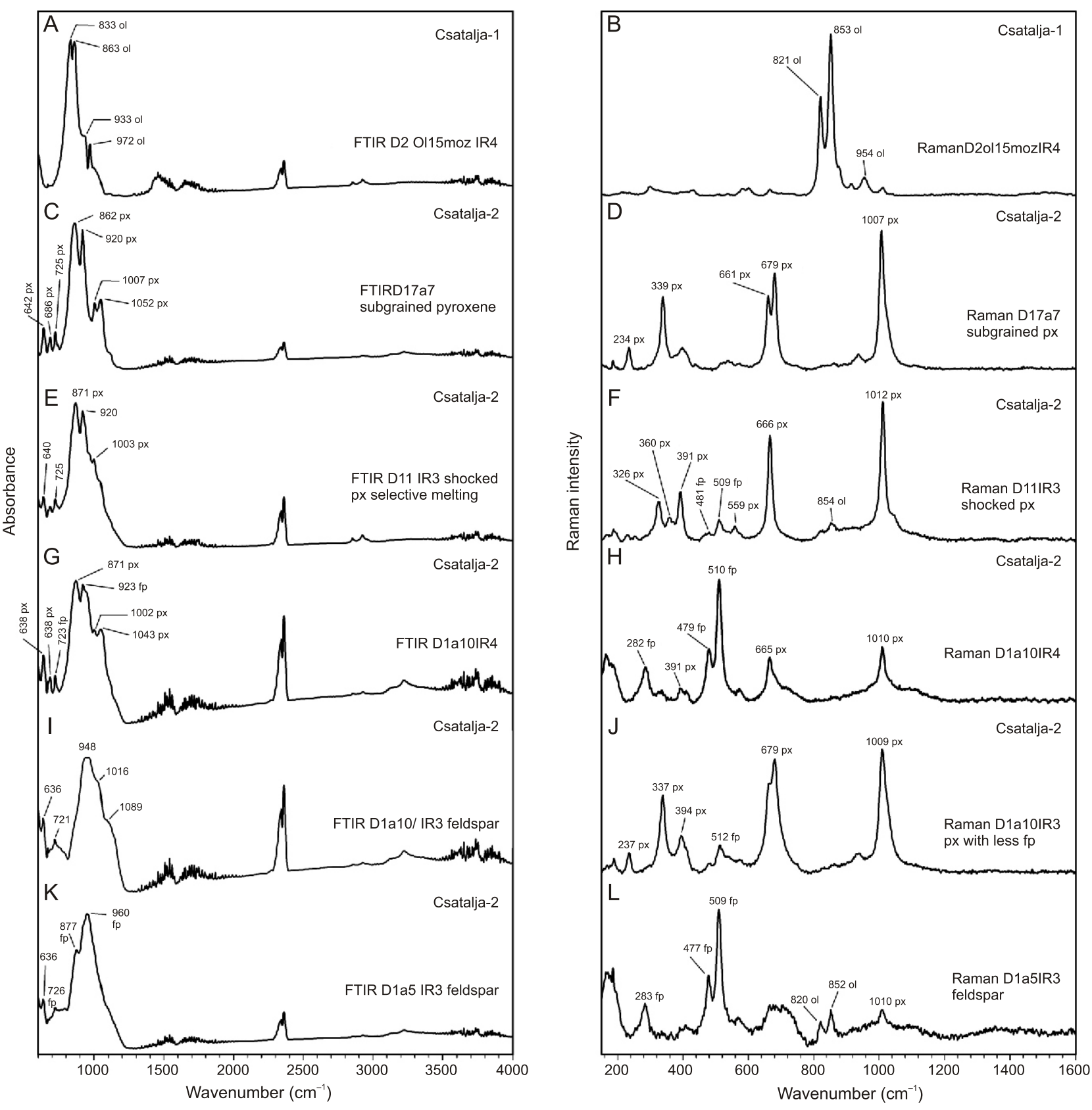

Fig. 2. Comparison of various shock level olivine (ol), pyroxene (px) and feldspar (fp) infrared and Raman spectra For detailed description please see the corresponding text. In the mixed cases the peaks are marked with the acronym of the corresponding mineral of the given peak ( $A-D, I, K$ - pure minerals, $\mathrm{E}-\mathrm{H}, \mathrm{J}, \mathrm{L}$ - mixed phases)

\section{SHOCK CHARACTERISTICS OF THE MINERALS IDENTIFIED}

The infrared and Raman methods were useful for the shock characterization of minerals, the shock-related parameters being described in this section. The measured IR and Raman band positions with FWHM values are listed in Appendices 1 and $2^{*}$. The shock-produced change in peak positions and FWHM values were compared to mineral reference data from unshocked samples of Earth-based materials, where the compositional reasons (measured by EMPA for the samples analysed in this work) for changes were excluded by using the same composition reference minerals (displayed in Appendices 1 and 2, columns 1 and 2). In general, the peak positions shifted to higher wavenumbers in infra-red and Raman spectroscopy (Appendices 1 and 2 column 2, column 6) with increasing shock stages (estimated initially by optical observation, then compared to Raman FWHM values of shocked mineral reference material, Rull et al., 2010), and show shift and broadening of peaks (Appendices 1 and 2 columns 4 and 8 ) 

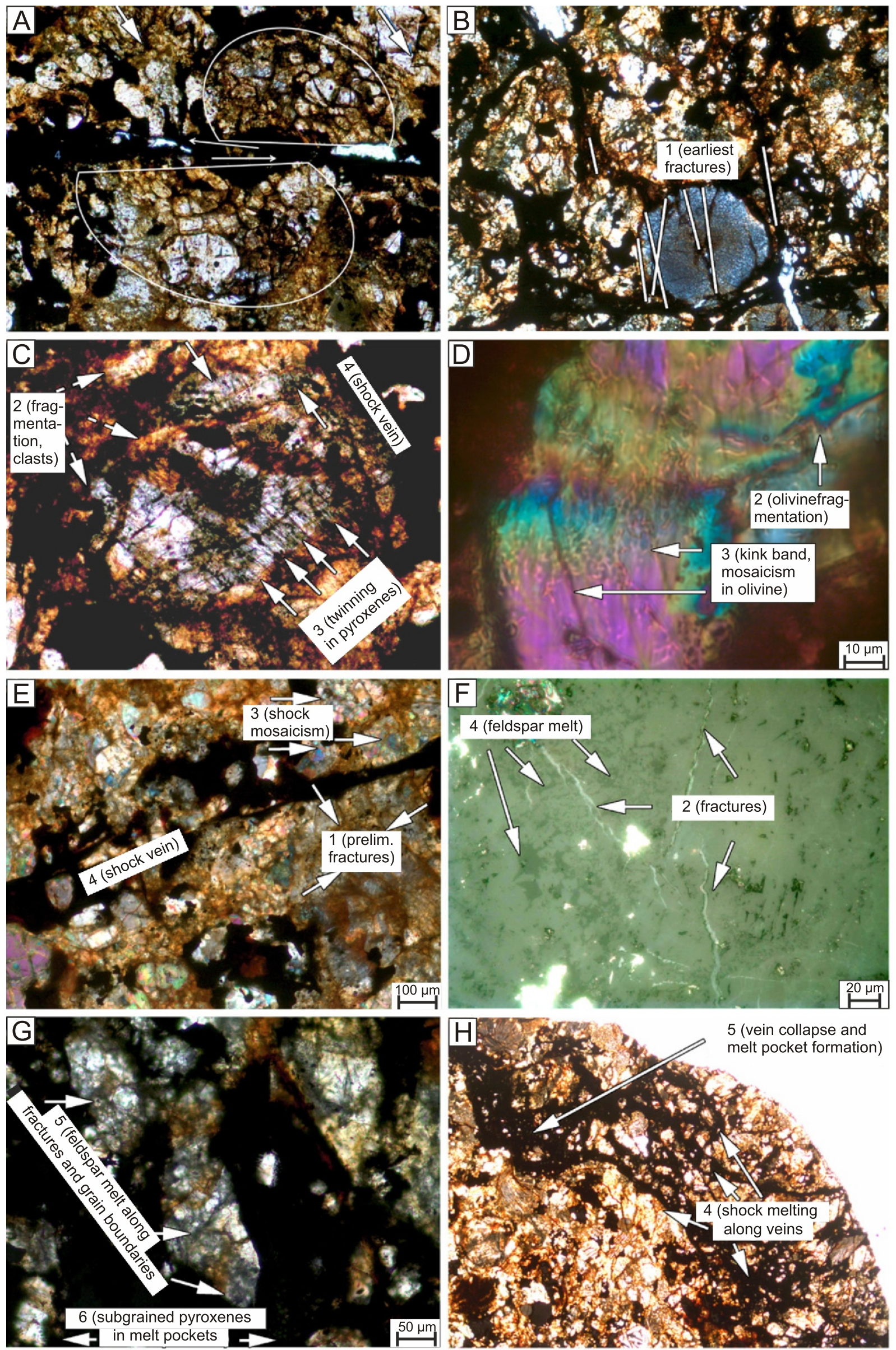
along with increasing shock deformation. Below we describe the mineral types and their behaviour, and subsequently by clean and mixed phases. The mixed phases occur in high shock stages (S5), characterized by higher FWHM values due to amorphisation, whereas clean phases were identified in less shocked locations (S3).

Olivines occur at many locations of the sample, including in the strongly shocked area D1, which are characterized by 70 Fo\% and low Raman shock-induced shift with $+2 \mathrm{~cm}^{-1}$. Olivines were abundant in the sample as mixed phases too, but they were rare as pure phases. They mostly transformed and the peaks could overlap with pyroxene peaks, making the identification difficult, and in mixed phases in clasts only Raman could identify them; IR method could not do this.

The pyroxenes are characterized by 3 end-member compositions (enstatite-diopside augite, >70 En\%, >40 Wo\%, $30 \mathrm{Wo} \%$, respectively), which have vibration bands at the following intervals and locations: 630-641, 670-690, 725, 920 $1007,1060 \mathrm{~cm}^{-1}$. High shock-induced IR shifts up to $-34 \mathrm{~cm}^{-1}$ due to deformation was observed; the major IR band at a position near $861 \mathrm{~cm}^{-1}$ has a shock-induced shift of $-6-+14 \mathrm{~cm}^{-1}$. The Raman bands of pyroxene have a shock-induced shift between -3 and $+13 \mathrm{~cm}^{-1}$, showing lower variation of these values than FTIR spectroscopy.

The feldspars' IR shifts vary between 28 and $32 \mathrm{~cm}^{-1}$, whereas the Raman shifts varies between -3 and $+1 \mathrm{~cm}^{-1}$. The feldspars are high-T plagioclase (lingunite) with compositions between oligoclase and labradorite. The highest IR peak shift from an unshocked reference could be observed by feldspars with values between -42 and $+28 \mathrm{~cm}^{-1}$ (Appendices 1 and 2 column 6 ), which could have been caused mainly by the shock effect but also influenced by the overlapping positions with pyroxene bands (the EMPA-based compositions were feldspar, but Ca-rich pyroxene was detected together with less feldspar by infrared and Raman spectroscopy) because of mixing of different mineral phases, and by considerable disordering of the crystalline lattice. The IR FWHM values are very high in the case of feldspars $\left(60-84 \mathrm{~cm}^{-1}\right)$ together with peak shift (see the examples in Appendices 1 and 2); these could be explained by amorphisation due to shock-induced crystal lattice defects These amorphized feldspars occur only in the strongly shocked area D1 in the melt pocket in the Csátalja-2 sample. In contrast to the IR data the Raman shock-induced shifts of feldspars are much smaller, with variation between -3 and $+2 \mathrm{~cm}^{-1}$, which is the same scale of shifted difference between IR and Raman methods that could also be observed in pyroxenes.

\section{CHARACTERISTICS OF CLEAN AND MIXED PHASES}

In this section the characteristic clean phases (where the observations showed peaks of only one mineral type at the given location) and mixed phases (where the observations showed peaks of two different minerals at the given location) of the minerals listed above are given, as they could provide insight into the shock-driven alterations. Clean feldspar spectra were detected only by FTIR spectroscopy (D1a5 IR1, D1a10
IR3, Csátalja-2), possibly because the ATR detects minerals to $\sim 0.5 \mu \mathrm{m}$ depth below the sample's surface, while Raman penetrates more deeply, to $\sim 3 \mu \mathrm{m}$ depth. Clean phases, with both infrared and Raman spectroscopy, were analysed for forsterite (D1a10 IR1 - Csátalja-2, D2/ ol15moz IR4 - Csátalja-1) and enstatite (D1a10IR3, D17a7 - Csátalja-2), magnetite (E6/1 magn 1-3 - Csátalja-1). In other cases, pure diopside (D11 IR2 - Csátalja-2), enstatite (D11 IR3 - Csátalja-2), and forsterite (D11 IR4 - Csátalja-2) phases were identified only by FTIR spectroscopy, but Raman spectroscopy detected mixed phases. In the following the mixed phases are described where in several cases more than one mineral's peak positions could be observed.

Mixed phases were detected by Raman spectroscopy on more occasions than pure phases: Csátalja-1: (4/9: 40\%, Csátalja-2: 12/15: 80\%); whereas the FTIR spectroscopy detected mixed phases in fewer cases $60 \%$ in Csátalja-1, $40 \%$ in Csátalja-2). Both Csátalja-1 and Csátalja-2 contain feldspar-pyroxene mixed phases, which are characterized below. Among the mixed phases observed, feldspars formed by melting around grain surfaces by the shock effect, while the olivines and pyroxenes there were primordial - in these cases the mixed phase reflects highly heterogeneous minerals that were partly produced by the shock itself.

A feldspar-pyroxene mixture was observed in 7 (33\%) cases (D2 rgt1_IR3, D3rgt2, D3px3 - Csátalja-1, D1a5IR2-4, D1a10IR2, D11 IR1, IR5-6 - Csátalja-2), which were detected by FTIR spectroscopy, while with Raman spectra the spectra were less mixed at these locations: with only traces of forsterite or pure diopside being observed. The Raman technique revealed forsterite in several mixed cases ( 3 cases: $37 \%$, D3tgt2 spectra in the Csátalja-1 sample, and 30\% D1a5 (IR3) and D11 (IR4-6) of the Csátalja-2 sample); forsterite in mixed mineral phases was not detected by FTIR spectroscopy, possibly as the olivine peak overlaps with those of pyroxene. Pyroxene was detected as a pure phase only in D3px3 Raman and FTIR spectra (Csátalja-1 sample).

Alkali-rich melts (a mixture of feldspar and Ca-rich pyroxene, which contains broad Raman and IR bands of low intensity), detected by elemental mapping, were concentrated along subgrain boundaries, while they were rare in the homogeneous melted material. They showed a darker grey, strewn appearance in reflected light using optical microscopy, suggesting shock annealing. The shock melt fraction has a feldspar composition with a high shock-induced shift in wavenumber, indicating the S5-S6 shock stage here.

The olivine is characterized by FWHM values of $12-19$, which indicate that peak shock pressure did not reach $15 \mathrm{GPa}$, with an estimated shock stage of between S3-S4. Detailed descriptions of the areas analysed as regards shock stages (based on optical analysis) are listed in Appendices 1 and 2, column 10

Amorphisation can be also measured by FWHM values, which increases with shock stages (Appendices 1 and 2, columns 4 and 8). Summarizing, the Csátalja-2 measured areas were highly shocked with S5 (shock-annealed clasts), and S6

\section{Fig. 3. Example features and their relations to reconstructing the shock history of the Csátalja meteorite}

A - shearing of chondrule in shock vein (Csátalja-1); B - brecciation and fracturing in Csátalja-1; C - fragmentation and mechanical twinning of pyroxene clast in a shock vein (Csátalja-1); $\mathbf{D}$ - fragmentation, kink bending and mosaic extinction of olivine (Csátalja-1); $\mathbf{E}$ - mosaic olivine in a shock vein and fracturing in the environment of the vein (Csátalja-1); $\mathbf{F}, \mathbf{G}-$ fragmentation and selective melting around subgrain boundaries of a pyroxene clast in a melt pocket, producing feldspar melt (Csátalja-2); $\mathbf{H}$ - collapse of shock veins producing a melt pocket (explanation in text); the different events are marked with numbers, see corresponding details in the text (A, B, G, H - transmitted light, C-E polarized light, F - reflected light images) 
(shock melt in melt pockets) shock stages. While the Csátalja-1 measured areas were less shocked, with S3-S4 shock stages (in shock veins). Total amorphisation was observed in a shock melt pocket, while the surrounding melt of a subgrained clast did not show any Raman signal with red laser. The S3-S4 shock stage were observed in clean phases with Raman and FTIR spectroscopy in and around shock veins, and mixed phases were detected at the S5 shock stage in a melt pocket. In a very few cases, mixed clasts also occur in shock veins (rgt1, rgt2 in the Csátalja-1 sample).

\section{SEPARATION OF DIFFERENT SHOCK EVENTS}

In meteorites shock events are often described. However, the separation of signatures from different shock events are less commonly reconstructed, partly as such decoding is difficult because different shock signatures could overwrite each other. In the following section the results of such an attempt is provided, while knowing that such a reconstruction of shock history is uncertain and several problematic features may be identified. During the reconstruction of the sequence of shock-related events, superpositional relation allowed identification of earlier fracturing, later formation of mosaic structure, then shock melting and collapse of shock veins. These events suggest increasing shock-produced changes with time. Although the time intervals between different shock events is unknown and could not be estimated (e.g., many millions of years or even minutes might have elapsed between two shock events), it is probable that most of these features represent different, separate shocks, thus different impact events.

The shocked areas (the fractured zone in the Csátalja-1, and melt pockets in the Csátalja-2 sample) contain olivine, pyroxene, feldspar melt, and metal-sulfide globules - providing ideal targets with their complexity to identify separate different shock signatures in the same area. The shock history of these characteristic parts of the meteorite is described by the superposition of shock features as follows (Fig. 3, with the minerals influenced and shock levels produced indicated in brackets in the list below). Although not all of the cross-cutting features could be identified in the same, relatively small area (e.g., the different relations could not be put into sequence of order at the same location), these superpositional connections could be observed at several locations, usually with two to three different types together in the same location. Along with this sequence of events, the later ones could erase those which occurred much earlier - for example shock melting has erased the earliest branching fractures in their neighbourhood, while no one case was observed where a branching feature crosscut a shock-melted area. In the following list each step represents one potential event, each being observed in several different parts of the samples:

1. Formation of the earliest, branching fractures, which are overwritten by all other shock features (Fig. 3A arrows, $B$ black fracture indicate these fractures) (fracturing of the parent body - breaking olivine and pyroxene minerals, S2).

2. Fracturing of clasts inside the parent body, sheared tectonic deformation in chondrules, microfaults (Fig. 3A-D) then formed. The sheared tectonic deformation elongated the clasts and chondrules, which were fragmented and sheared along preliminary fractures (fracturing of olivine, pyroxene clasts - producing polycrystalline, fine-grained aggregates, S2).

3. Formation of mosaic structure in olivine, mechanical twinning of pyroxenes, planar fractures, kink-band for- mation in olivine in the vicinity of earlier fractures. The mosaic olivines occur inside shock veins with fragmented clasts and chondrules with microfaults (Fig. 3A-E, olivine, pyroxene, S3-S4).

4. Shock melting along veins, formation of feldspar melt with metal-sulphide globules embedded inside feldspar melts. In this phase relatively less melt was produced than later (Fig. 3A, E, H, feldspar melt, troilite and kamacite globules, S5).

5. Collapse of shock veins due to the progressive front of a new second shock wave, especially along the previously formed shock veins with the formation of melt pockets including relatively larger melt volumes then earlier (Fig. $3 \mathrm{H}$ ). As the shock wave preferably propagated along preliminary fractures of branching shock veins (Sharp and DeCarli, 2006), and if the propagation of the new shock wave was perpendicular to preliminary shock veins and fractures, these branching shock veins collapsed producing shock melt pockets (Sharp and De Carli, 2006), together with sulphide globule formation. The morphology visible in inset $\mathrm{H}$ is compatible with this idea (in feldspar melt, troilite, kamacite, S5).

6. Post-shock annealing along fractures and subgrains of mineral clasts, producing mixed mineral clasts. Subgrain features and melting along fractures of clasts occurred only in the melt pockets (5 phases), while in the shock veins this was not observed. The post-shock annealing overprinted the mosaic structure in olivine only in the melt pockets, while in the thinner melt veins the mosaic structure was not destroyed. The subgrain production was initiated by preliminary fractures and cleavages from earlier shock events formed during phases $1-3$ of each mineral clast. The high temperature shock-related alterations produced subgrained structure in mosaic olivines and twinned pyroxenes (Fig. 3E). The subgrained structure might have been initiated by the formation of high pressure polymorphs (with homogeneous nucleation growth - Chen et al., 2004), but in this case the shock pressure loading time $(<1 \mathrm{~ms}$ in non-porous rock; Sharp and DeCarli, 2006) was too short to form high pressure phases (S6).

\section{DISCUSSION}

In this section, observations on certain minerals are first discussed in order to see what conditions were present during their formation. Then, the Raman and infrared analysis-based shock-driven changes are compared to see any connection between these two groups of results. Thirdly the shock-related formation conditions are outlined based on these findings. Fourthly the possible shock history is outlined, partly to see how far these methods allow the reconstruction process and where are the related future perspectives. Finally some methodological experiences are also summarized, which may be useful for the planning of related work in the future, partly supporting the activity of the community, including the band shift and FWHM data as SOM in Appendices 1 and 2.

The FWHM shows crystallization rate, and not directly the shock stage (Nakamuta and Motomura, 1999); however, it gives insight to the shock reconstruction if completed with other indicators such as peak position shift, as the shock could modify the FWHM too and optically based identification of mosaic structure also point to shock effect. For example, a brecciated chondrule fragment has a FWHM of $30 \mathrm{~cm}^{-1}$, but this may have 
been caused by weak crystallization of pyroxene due to rapid cooling rate of the chondrule with a weak shock metamorphic overprint. As the change in FWHM is accompanied with shift in peak positions, pointing to the existence of shock pressure as well as elevated temperature-driven alteration. The mosaic olivines and pyroxenes show similar Raman FWHM of $12-16 \mathrm{~cm}^{-1}$ in the Csátalja-1 sample indicating the $\mathrm{S} 3$ shock stage.

Publications based references of FWHM values were compared to the Raman spectroscopic and FTIR measurements of olivines and pyroxenes in this work. The unshocked olivines are characterized by main doublet peak positions of 820 and $850 \mathrm{~cm}^{-1}$ (Rull et al., 2010), with FWHM $10 \mathrm{~cm}^{-1}$ (Miyamoto and Ohsumi, 1995). According to Miyamoto and Ohsumi (1995), the shocked olivine with $21 \mathrm{~cm}^{-1}$ FWHM (characterized also by the corresponding peak shift) proposed shock stage is $15 \mathrm{GPa}$, $900^{\circ} \mathrm{C}$. In the sample analysed the Csátalja-1 olivines have FWHM values varying between 15 and $17 \mathrm{~cm}^{-1}$ (S3 shock stage), whereas the FWHM values in Csátalja-2 olivines are $12-32 \mathrm{~cm}^{-1}$ (S3-S5 shock stage). The Csátalja-1 olivines occur in the less shocked branching shock vein, while the Csátalja-2 olivine analysed occurs in a more shocked melt pocket (FWHM $=26-32 \mathrm{~cm}^{-1}$ ) and is moderately shocked (FWHM = $\left.12-20 \mathrm{~cm}^{-1}\right)$. The measured olivines show mosaic extinction and demonstrate a narrow range but different shock level alterations.

Similarly to olivines, the FWHM of the major band at $1004 \mathrm{~cm}^{-1}$ of unshocked pyroxenes are characterized by FWHM values of $10 \mathrm{~cm}^{-1}$. According to Rull et al. (2010), shocked pyroxenes in the S3-S4 chondrites show $16-21 \mathrm{~cm}^{-1}$ FWHM at the major band of $1009 \mathrm{~cm}^{-1}$ near to unshocked pyroxenes with FWHM near to $10 \mathrm{~cm}^{-1}$. The FWHM values of pyroxenes in the Csátalja samples vary between 12 and $30 \mathrm{~cm}^{-1}$ (Csátalja-1: $12-30 \mathrm{~cm}^{-1}$, Csátalja-2: $15-30 \mathrm{~cm}^{-1}$ ), which exceed the S3 shock level. The most heavily shock-annealed pyroxenes in our sample are characterized by FWHM between 33-66 cm $\mathrm{cm}^{-1}$ indicating S5 shock stage. Averagely the Csátalja-1 sample pyroxenes are characterized by lower FWHM $\left(16.8 \mathrm{~cm}^{-1}\right)$ than the Csátalja-2 sample $\left(18.4 \mathrm{~cm}^{-1}\right)$. This is in agreement with the olivine based slight differences in shock levels from the FWHS of olivines. An increase of FWHM along with the increasing shock level of pyroxenes was observed in the sample, however, FWHM values do not follow optically based shock estimation due to potential recrystallization of the mineral clasts. These pyroxenes have shock features indicating 15-16 $\mathrm{Pa}$ and $1000^{\circ} \mathrm{C}$ conditions.

Altogether 8 measurements showed feldspars, which occur only as mineral melt along the subgrain boundaries of strongly shocked clasts in the shock veins of the Csátalja-1 sample and in the melt pocket of the Csátalja-2 sample. Fritz et al. (2005) suggest that unshocked plagioclase has Raman FWHM $12 \mathrm{~cm}^{-1}$, and shocked plagioclases (5-20 GPa) are characterized by $13-20 \mathrm{~cm}^{-1}$ of band $505 \mathrm{~cm}^{-1}$, while the feldspar glass (above $25 \mathrm{GPa}$, Fritz et al. 2005) has FWHM values $>25 \mathrm{~cm}^{-1}$. Comparing the two samples the feldspars in Csátalja-1 are a little less crystallized (Raman FWHM values $14-18 \mathrm{~cm}^{-1}$, average $16 \mathrm{~cm}^{-1}$ ) than in Csátalja-2 (FWHM 13-17, average $15 \mathrm{~cm}^{-1}$ ) due to possibly more rapid cooling in a shock vein than in a melt pocket. In Csátalja-2 the feldspars occurred together with forsterite in Raman spectra, while olivine was not detected in FTIR spectra of mixed clasts. In the Csátalja- 1 sample, feldspars occur as minor phases of nearby pyroxenes in the FTIR spectra, while in Csátalja-2 feldspars were dominant in the pyroxene-feldspar mixture - probably because the higher shock effect in Csataolja-2 produced more feldspar in the melted phase. Our Raman FWHM values of $505-511 \mathrm{~cm}^{-1}$ band vary between 13 and $17 \mathrm{~cm}^{-1}$ in the Csátalja-2 sample suggesting 5-18 GPa shock influence, while the FWHM in the Csátalja-1 sample points to 5-10 GPa.

\section{CORRELATION ANALYSIS}

The observations provided above could be used jointly to analyse or even improve shock level estimation based on optical, Raman and infrared properties together. The measured Raman and infrared peak shifts and FWHM values were analysed to establish correlations between these parameters and optical observation-based shock stage estimation. There are relatively few data points in the correlation diagrams in Figure 4 because of observational constraints from the many mixed phases - thus although the results are uncertain, they are still useful and fit to the expectations of shock-driven alterations and they point to a probably fruitful future direction. Here only reliable data point pairs were shown, demonstrating that correlation exists - however, the specific values should be gradually improved in the future by analysing more meteorites among the community. Correlations were calculated first between Raman peak shift and Raman FWHM, later IR peak shift and IR FWHM values, and finally between Raman and IR measurements. The data values used are shown in Tables 1 and 2, however, the correlation parameters listed could be considered only as indicators of various correlations, but further analysis is necessary with other meteorites to confirm these results.

Analysing Tables 1 and 2, both of IR and Raman shock-induced shifts, indicate correlation (Fig. 4) with their FWHM parameters in the case of pyroxenes of the Csátalja-1 $\left(R^{2}=0.97\right)$ and Csátalja-2 $\left(R^{2}=0.85\right)$ samples; however, further meteorites should be analysed to confirm this relation. The IR and Raman FWHM values of pyroxenes also indicate correlation in the Csátalja-1 sample $\left(R^{2}=0.78\right)$, whereas the Csátalja- 2 pyroxenes are characterized by lower values $\left(R^{2}=0.63\right)$. The Csátalja-1 pyroxenes are monomineralic clasts, whereas the Csátalja-2 pyroxenes are mixed mineral clasts with selective melting around subgrain boundaries - this could be the reason for the difference. Subgrain formation is a transitional state to high pressure structure, as Chen et al. (2004) described in the case of olivine-ringwoodite and pyroxene-akimotoite transition by "homogeneous nucleation growth" at $18 \mathrm{GPa}$, which melt has a feldspar composition, probably in connection with stronger shock effect.

The feldspars occur as mixed mineral melt with pyroxenes and olivines in Raman spectra, and pure feldspars were detected only by FTIR. However, the EMPA-based compositions showed these grains are feldspars, but in Raman spectra in many cases pyroxenes were the more dominant phases. In FTIR spectra the feldspar peaks overlapped with those of pyroxenes, hence the feldspar data were not suitable for correlation calculations. At the same time it was demonstrated that the infiltration of alkali-rich melt happened along the subgrain boundaries and fractures of pyroxenes (Fig. 4).

The correlation of IR and Raman parameters indicates cotemporary increase of FTIR and Raman shock-induced shift with FWHM- see further details in Table 2 - however, unfortunately these candidate correlations could not be analysed with a larger number of data points. FWHM increases with increasing shock stage in agreement with Rull et al. (2010), also along with the increasing shift of peak positions. These features are caused by the damage to the crystalline lattice due to increasing shock stage and confirm that both methods could be used for the estimation of shock-related levels.

In the Csátalja-1 sample, the Raman and FTIR peak shifts vary in a narrow range compared to the references with similar 

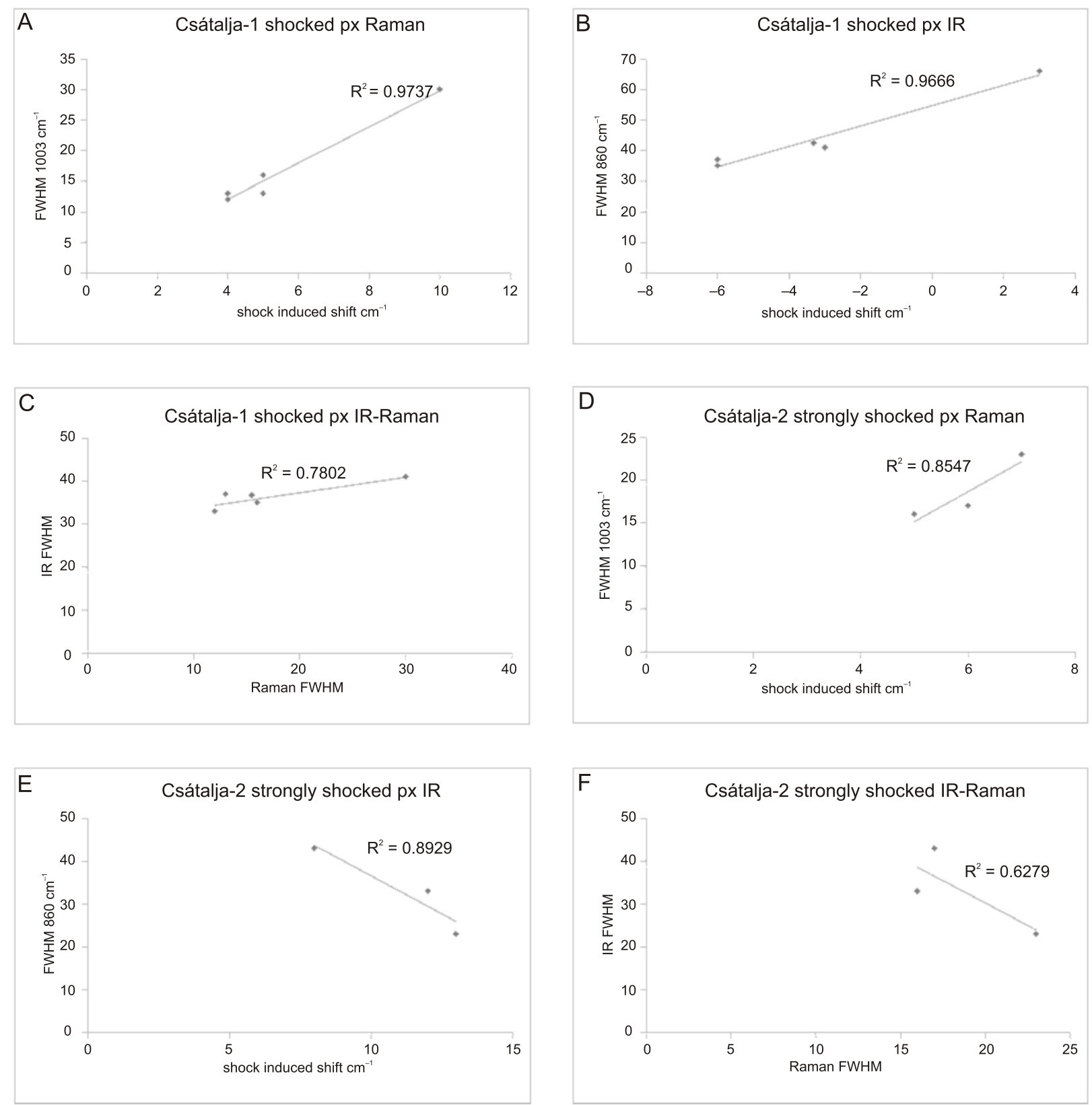

Fig. 4A, B - correlation diagrams of shocked feldspar; C, E - correlation diagrams of shocked pyroxene; $\mathrm{F}, \mathrm{H}$ - correlation diagrams of strongly shocked pyroxenes

In subsets $B$ and $C$ the two points closest to each other were overlapping points, thus separated from each other only for visualization of the numbers

compositions, while Raman and FTIR FWHM show similar variation to each other. But Raman FWHM does not exceed the value of the strongly shocked olivines with $21 \mathrm{~cm}^{-1}$, hence the S3-S4 shock stage could be expected. The difference between Raman and IR parameters for feldspars and pyroxenes are more characteristic when compared to olivine; generally, the IR FWHM values are much higher than the Raman FWHM values. The high IR FWHM of pyroxenes and feldspar could be caused by shock heat and this frictional shock melting follows the subgrain boundaries and fractures.

In Csátalja-2 sample, the shock-induced IR and Raman shifts show similar trends to each other, but the IR FWHM maximum is much larger than the FWHM of Raman spectroscopy probably due to heat effect or annealing. The comparison of IR and Raman parameters indicates correlation in the case of less shocked pyroxene. In the case of strongly shocked pyroxene the Raman shock-induced shift of $1003 \mathrm{~cm}^{-1}$ correlates with shock-induced shift, whereas the IR FWHM correlates with Raman shock-induced shift, and IR FWHM with Raman FWHM. The IR FWHM of shock feldspar melt correlates with shock-induced shift, whereas IR-Raman correlate each other however, the data gained from this meteorite provides only an indication of correlation. The difference in Raman and IR peak changes might be related, as Raman is sensitive to shorter length, and infrared to greater length ordering/disordering in the crystalline lattice (Nasdala et al., 2004). The Raman FWHM varies in similar range for both pyroxenes and feldspars, but their shock-induced shift is higher in the case of feldspars than in pyroxenes. This high IR and Raman FWHM indicate elevated shock temperature $>900^{\circ} \mathrm{C}$ in the shock melt pocket.

According to Raman FWHM parameters, the feldspar melt could be influenced also by shock annealing, and the Raman 
FWHM values $<20 \mathrm{~cm}^{-1}$ point to $<15 \mathrm{GPa}$ (Fritz et al., 2005), while high IR FWHM values imply strong amorphisation with peak shock pressure at $14 \mathrm{GPa}$. Polycrystalline mixed mineral clasts are a transition stage to high pressure transformation (Chen et al., 2004; Sharp and DeCarli, 2006; Miyahara et al., 2010). However, high pressure phases could be not identified. Wadsleyte crystallizes at $16 \mathrm{GPa}$, and the ringwoodite at 17-23 GPa at $1000-1200^{\circ} \mathrm{C}$ (Chan et al., 2004; Xie et al., 2006). The lack of high-pressure polymorphs indicates that the shock pressure did not exceed $16 \mathrm{GPa}$.

\section{EVALUATION OF ESTIMATED SHOCK STAGES}

In a meteorite, the shock stage-related alteration of minerals is usually heterogeneous, strongly influenced by the mineral composition and by pre-shock structures, and by the consequences of subsequent shock events on each other. Analysing the optical appearance, consequence of changes of crystalline structure, the presence of amorphous phases and mineral melt together with Raman and infrared spectral characteristics, the following statements may be made. Cataclasitic texture may occur at the S3 shock stage, whereas a high amount of shock melt in an area implicates the S5 shock stage according to the classification of Stöffler et al. (1991). The Raman-IR parameters seem to correlate with the interpreted shock stages according to petrographic observation. The feldspars occur only in shock veins and melt pockets around the subgrain boundaries of pyroxene clasts. As a summary, FWHM values of pyroxenes occasionally indicate different shock stages (S3-S4) than do the optical observations. Csátalja-2 pyroxenes and olivines are more strongly shocked than in the reference value of Kovács et al. (2015b) as the first measurement from the same meteorite. The minerals in mixed clasts show similar shock stages to each other in the Csátalja-2 sample (S4-S5). The Csátalja-1 has peak shock stage inside the vein varying between S3-S5, and the Csátalja-2 shock melt pocket is characterized by a shock stage between S5 and S6 from the optical description and FTIR-Raman data.

The higher shock-induced IR shift of the Csátalja-2 sample than in Csátalja-1 is caused by a higher amount of shock melting. Comparing our Raman FWHM values to those of Kovács et al. (2015b) on this meteorite, the peak shock pressure somewhat exceeded $15 \mathrm{GPa}$ in the case of olivines, so higher than Kovacs et al. estimated.

\section{FORMATION CONDITIONS}

Altogether with jointly using Raman and infrared measurements, in two cases $S=3$, in one case $S=4$, in three cases $S=5$ and in two cases $S=6$ shock levels were identified. Moderate but observable differences exist between the two characteristic shock alterations produced and location types analysed: (1) in a shock vein (Csátalja-1, Table $1 \mathrm{SOM}$ ), the witnessed shock $\mathrm{p}-\mathrm{T}$ was between $700-900^{\circ} \mathrm{C}$ and $10-15 \mathrm{GPa}$, and the shock veins formed along the weakness zones, like preliminary fractures; (2) in a melt pocket (Csátalja-2, Table 2 SOM), the peak shock pressure reached 15-16 GPa. Because of the lack of high pressure transition phases (ringwoodite, akimotoite, majorite, lingunite), the shock pressure nowhere reached $17 \mathrm{GPa}$. The feldspar occurs only as a minor phase in mixed mineral clasts together with pyroxene with FWHM values of $12-18 \mathrm{~cm}^{-1}$, which formed by shock melting at $900^{\circ} \mathrm{C}$. Thus, the shock stage of shocked feldspar is expected between 5-20 GPa following the Fritz et al. (2005) classification for the Csátalja-2 sample. The Raman FWHM values were lower in the case of pyroxenes and feldspars, than for FTIR spectra for both the Csátalja-1 and Csátalja-2 samples.
Similar shock-induced shift was observed for pyroxenes by the Raman and IR methods (in contrast to the case with feldspars), indicating S3-S5 values; the highest values were observed in subgrained pyroxenes. The highest FWHM for pyroxene occur in shock melt around the subgrain boundaries of the shock-annealed clast (Csátalja-1), and in shock melt along the fractures (Csátalja-2). Summarizing, the Csátalja-1 contains pyroxene-rich melt as shock-annealed subgrained clasts, whereas in Csátalja-2 the feldspar is the major phase in shock melt that occurs around the subgrains and fractures of pyroxene formed by selective melting at weakness zones. The highest IR FWHM values were observed in feldspar melt in Csátalja-2, while the Csátalja-1 feldspar melt was less amorphized. The original magmatic pyroxenes crystallized at $1100^{\circ} \mathrm{C}$, which transformed to subgrained aggregate at the S5 shock stage, and shock melt with feldspar composition around the subgrains formed at $15 \mathrm{GPa}$.

Shock-related formation of feldspars is suggested based on their occurrence close to grain edges only at the heavily shocked locations and also based on the signature of shock deformation in their infrared spectra. As feldspars were observed only at shocked sites along grain boundaries, they are probably secondary minerals formed by the shock event from the elements released by pyroxenes and olivines. Kamacite and troilite globules are also secondary phases, produced in shock veins and melt pockets with an immiscible feldspar composition silicate melt. The shock wave propagation was more rapid along the first-formed fractures (which could have been formed by an earlier shock or tectonic event). While the shock-related spectral features could be identified in pyroxenes and olivines both by Raman and infrared methods, for feldspars only the infrared method was possible for this. This difference is probably not related to the small size of the feldspars as Raman has better spatial resolution than the infrared method, but may be connected to the better ability of infrared observation to identify the damaged crystalline structure of feldspars, in agreement with some earlier findings (Gyollai et al., 2012).

The FWHM and peak shift values clearly demonstrated the different levels of shock effects: the high infrared FWHM values occur in mixed clasts with signatures of selective melting, while in less shocked clasts only a minor shock-induced peak shift was observed. Mixed phase minerals were detected both by Raman and FTIR methods in Csátalja-2, while in Csátalja-1 only Raman detected mixed phases. The cause of this difference is probably that the measuring points of Csátalja-2 sample were in a shock melt pocket, whereas in Csátalja-1 the shock-related amorphization and recrystallization was not as pervasive. The broadening of peaks implies amorphisation due to crystal lattice broadening by heat from the shock. In contrast to this olivine and pyroxene are primary minerals, which were deformed and even amorphised by shock annealing.

\section{IMPLICATIONS}

The two units analysed (two thin sections) of the meteorite with different shock-produced morphology were analysed in more detail: branching shock veins with mineral clasts (mosaic extinction olivine, pyroxene with isotropic patches) and a chondrule fragment in Csátalja-1. While in Csátalja-2 a melt pocket with mixed mineral clasts (selective melting along the subgrain boundaries) was analysed. The feldspars formed by selective melting of pyroxenes along the subgrain boundaries by shock annealing. Pure feldspar spectra could be detected only by FTIR spectroscopy, and the highest infrared FWHM values were observed in amorphized/recrystallized feldspar spectra, which occur only as shocked clasts in the melt phase. Most of 
the spectra (Csátalja-1: 60\%, Csátalja-2: 70\%) were a mixture of minerals formed by selective melting of olivine and pyroxene around the subgrain boundaries and fractures. The clasts in Csátalja-1 showed monomineralic composition, and separated with parallel shock veins. Here the shock pressure did not exceed $15 \mathrm{GPa}$, while the Csátalja-2 mineral clasts often show mixed mineralogy, larger shock melt volume, the pyroxene and olivine clasts are surrounded by feldspar melt along the subgrain boundaries, indicating $>15 \mathrm{GPa}$ shock pressure - but $<17 \mathrm{GPa}$ as transformation to akimotoite and ringwoodite was not observed.

Our data indicates that both Raman and infrared peak shifts and FWHM values seem to correlate with each other along with the increasing shock level according to theoretical expectations. The best indication of correlation (Raman FWHM vs. shock-induced shift) occurred in shocked pyroxene. The shock-induced shift of peak position varied similarly in the case of olivines and pyroxenes by FTIR and Raman spectroscopy, but for feldspars the shock-induced shifts of peak position was much higher in infrared than in Raman methods. The correlation was stronger both for FTIR- and Raman-based parameters in the less shocked Csátalja-1 sample.

The examples shown demonstrate the complexity of shock level estimation. The optically interpreted S3 staged chondrule fragments showed similar or higher spectrally based values by comparison with S5 staged shock annealed clasts, while the highest increase in FWHM values could be observed in shock melt at the S6 shock stage. Generally, the measured Raman FWHM values are smaller than the optically observed shock stage, probably due to recrystallization, which might hide the maximum pressure that the given mineral grain witnessed. This fact should be considered during the comparison of modern shock level estimation to older optically based meteorite data. The mixed clasts (pyroxene with feldspar around the subgrain boundaries and fractures) show Raman FWHM values around S3-S5 depending on recrystallization, the fractured clasts with strong mosaic structure indicates higher shock deformation than our optical observations - demonstrating that recrystallization modifies the shock estimation. The mixed mineral clasts in a shock melt pocket formed within 15-16 GPa pressure and up to $1000^{\circ} \mathrm{C}$ temperature. Feldspar minerals were identified at the heavily shocked locations along grain boundaries and they formed as secondary minerals because of the strongest shock event.

Some methodological findings were also achieved during the work. The weakly crystallized minerals could be better detected by infrared than by Raman spectroscopy because infrared spectra show long-range structural ordering of minerals (Xu and Poduska, 2014). The Raman and infrared spectroscopy also showed differences not only because of the higher magnification and smaller field of view in Raman than infrared but also as Raman detects $2-3 \mu \mathrm{m}$ depth in the sample, whereas infra- red penetrates only $0.5 \mu \mathrm{m}$ depth. Raman spectroscopy could also better detect the minor mineral phases, because the feldspar and pyroxene bands do not overlap - thus mixed clasts could be better measured by Raman. However, the secondary feldspars were identified only by infrared methods. Substantial heterogeneity of the shock stage was observed across a 10-100 $\mu \mathrm{m}$ spatial distance in both the Csátalja-1 and Csátalja-2 samples, questioning the characterization of just one shock stage value for one meteorite.

\section{CONCLUSIONS}

Consequences of shock-produced mineral alterations were studied, compared and put into potential temporal sequence of order in a recently found ordinary chondrite meteorite (Csatalja) using optical, Raman and infrared analysis. All minerals analysed demonstrated the effect of shock-related melting and structural disordering, and formation of new minerals by the shock. The less shocked branching veins showed mosaic extinction and isotropic patches, while in the more shocked melt pockets new minerals (feldspars) were formed by selective melting of pyroxenes along the subgrain boundaries.

The more shocked (S5) phases usually were mixed phases (with high shift in peak position and larger FWHM), while pure phases appeared around S3. Three parallel trends were identified along with the increasing shock stages: shift in peak position, broadening of peaks and increasing the occurrence of mixed phases. Band position shift and FWHM changed parallel to each other, the infrared and Raman data obtained being provided as SOM for the community; for firm correlation analysis more data is necessary from other shocked meteorites.

Using the shock features and superpositional relationships identified, mechanical fracturing without crystalline lattice deformation happened at least in two different early phases $(1,2)$. Later, mosaic structure-producing shock events followed (3), and even later more stronger shocks took place, producing melt veins (4). Finally, by the collapse of many such veins, melt pockets were produced (5), and subsequent shock annealing happened (6). The maximum observed shock pressure was between 15-17 GPa. The separation of 4-5 shock events support the identification of the earlier emergence of lower shock levels followed by stronger shock effects.

Acknowledgements. This work was supported by NKFIH with the GINOP-2.3.2-15-2016-00003 fund. The authors are grateful to the MTA for funding the Size, Shape, Identity laboratory, to the HAS Research Centre of Astronomy and Earth Sciences, to the University of Szeged for the instrumental background, and also for the helpful comments and suggestions of the two referees: Anonymous and J. Kovács.

\section{REFERENCES}

Basavaiah, N., Shriram, C.R., 2013. Spectral changes with the direction of asteroid impact at Lonar crater, India: findings from Mid-IR DRIFT analysis. EGU General Assembly, abstract EGU2013-7681.

Beck, P., Gillet, P., El Goresy, A., Mostefaoui, S., 2005. Timescales of shock processes in chondritic and martian meteorites. Nature, 435: 1071-1074.
Borucki, J., Stępniewski, M., 2001. Mineralogy of the Baszkówka chondrite (L5 S1): new data on silicates, opaques and minor minerals. Geological Quarterly, 45 (3): 229-255.

Borucki, J., Giro, L., Orłowski, R., Stępniewski, M., 2009. The Songyuan ordinary chondrite (China) - rich in alien rock fragments and its reclassification. Geological Quarterly, 53 (2): 187-198. 
Chemtob, S.M., Glotch, T.D., Rossman, G.R., 2010. ATR-IR spectroscopy for in situ mineral analysis on planetary surfaces: steps toward a forward model. 41th Lunar and Planetary Science Conference, abstract 2198.

Chen, M., El Goresy, A., Gillet, P., 2004. Ringwoodite lamellae in olivine: clues to olivine-ringwoodite phase transition mechanisms in shocked meteorites and subducting slabs. Proceedings of the National Academy of Sciences of the United States of America, 101: 15033-15037.

De Benedetto, G.E., Laviano, R., Sabbatini, L., Zambonin, P.G., 2002. Infrared spectroscopy in the mineralogical characterization of ancient pottery. Journal of Cultural Heritage, 3: 177-186.

Doménech-Carbó, M.T., de Agredos-Pascual, M.L.V., Osete-Cortina, L., Doménech-Carbó, A., Guasch-Ferré, N., Manzanilla, L.R., Vidal-Lorenzo, C., 2012. Characterization of prehispanic cosmetics found in a burial of the ancient city of Teotihuacan (Mexico). Journal of Archaeological Science, 39 1043-1062.

Downs, R.T., 2006. The RRUFF Project: an integrated study of the chemistry, crystallography, Raman and infrared spectroscopy of minerals. 19th General Meeting of the International Mineralogical Association in Kobe, Japan, abstract no. 003-13.

Ferguson, P., 2010. Attenuated Total Reflectance-Fourier Transform Infrared Spectroscopy Analysis of Pulsed Electron Deposited Silicon Dioxide Film on Silicon Substrate (Doctoral dissertation, Texas State University-San Marcos), pp. 75.

Fintor, K., Park, C., Nagy, Sz., Pál-Molnár, E., Krot, A. 2014. Hydrothermal origin of hexagonal $\mathrm{CaAl}_{2} \mathrm{Si}_{2} \mathrm{Os}$ (dmisteinbergite) in a compact type A CAI from the Northwest Africa 2086 CV 3 chondrite. Meteoritics and Planetary Sciences, 49: 812-823.

Foster, N.F., Wozniakiewicz, P.J., Price, M.C., Kearsley, A.T., Burchell, M.J., 2013. Identification by Raman spectroscopy of $\mathrm{Mg}-\mathrm{Fe}$ content of olivine samples after impact at $6 \mathrm{kms}^{-1}$ onto aluminium foil and aerogel: in the laboratory and in Wild-2 cometary samples. Geochimica et Cosmochimica Acta, 121: $1-14$.

Freeman, J.J., Wang, A., Kuebler, K.E., Jolliff, B.L., Haskin, L.A. 2008. Characterization of natural feldspars by Raman spectroscopy for future planetary exploration. The Canadian Mineralogist, 46: 1477-1500.

Fritz, J., Greshake, A., Stöffler, D., 2005. Micro-Raman spectroscopy of plagioclase and maskelynite in Martian meteorites: evidence of progressive shock metamorphism. Antarctic Meteorite Research, 18: 96

Gyollai, I., Gucsik, A., Nagy, S., Bérczi, S., 2012. Petrographic and mid-infrared spectroscopy study of shocked feldspar in the Asuka-881757 Lunar gabbro meteorite sample. Central European Geology, 55: 23-32.

Hałas, S., Wójtowicz, A., 2001. K/Ar dating and stable isotope analysis of the Baszkówka and Mt. Tazerzait L5 chondrites. Geological Quarterly, 45 (3): 315-317.

Huang, E., Chen, C.H., Huang, T., Lin, E.H., Xu, J.A., 2000 Raman spectroscopic characteristics of $\mathrm{Mg}-\mathrm{Fe}-\mathrm{Ca}$ pyroxenes. American Mineralogist: 473-479.

Johnston, C.T., Premachandra, G.S., 2001. Polarized ATR-FTIR study of smectite in aqueous suspension. Langmuir, 17 3712-3718.

Kereszturi, A., Gyollai, I., Szabó, M., 2015. Case study of chondrule alteration with IR spectroscopy in NWA 2086 CV3 meteorite. Planetary and Space Science, 106: 122-131.

Koizumi, E., Mikouchi, T., Monkawa, A., Kurihara, T., Miyamoto, M., 2010. Micro FT/IR Analysis of Brown Olivines in Martian Meteorites. 41st Lunar and Planetary Science Conference, abstract 1575

Kovács, I., Udvardi, B., Falus, Gy., Földvári, M., Fancsik, T., Kónya, P., Bodor, E.R., Mihály, J., Németh, Cs., Czirják, G. Ősi, A., Vargáné Barna, Zs., Bhattoa, H.P., Szekanecz, Z. Turza, S., 2015a. Practical - especially Earth science - applications of ATR FTIR spectrometry through some case studies (in Hungarian with English summary). Földtani Közlöny, 145 173-192.
Kovács, J., Sajó, I., Márton, Z., Jáger, V., Hegedüs, T., Berecz, T., Tóth, T., Gyenizse, P., Podobni, A., 2015b. Csátalja, the largest H4-5 chondrite from Hungary. Planetary and Space Science, 105: 94.

Krzesińska, A.M., 2016. Thermal metamorphic evolution of the Pułtusk $\mathrm{H}$ chondrite breccia - compositional and textural properties not included in petrological classification. Geological Quarterly, 60 (1): 211-224.

Kuebler, K.E., Jolliff, B.L., Wang, A., Haskin, L.A., 2006. Extracting olivine (Fo-Fa) compositions from Raman spectral peak positions. Geochimica et Cosmochimica Acta, 70: 6201-6222.

Lane, M.D., Glotch, T.D., Dyar, M.D., Pieters, C.M., Klima, R., Hiroi, T., Bishop, J.L., Sunshine, J., 2011. Midinfrared spectroscopy of synthetic olivines: thermal emission, specular and diffuse reflectance, and attenuated total reflectance studies of forsterite to fayalite. Journal of Geophysical Research, 116 (E8): E003588.

Madejová, J., 2003. FTIR techniques in clay mineral studies. Vibrational Spectroscopy, 31 (1): 1-10.

Madejova, J., Komadel, P., 2001. Baseline studies of the clay minerals society source clays: infrared methods. Clays and Clay Mineralogy, 49: 410-432.

Miyahara, M., Ohtani, E., Kimura, M., El Goresy, A., Ozawa, S., Nagase, T., Hiraga, K., 2010. Coherent and subsequent incoherent ringwoodite growth in olivine of shocked L6 chondrites. Earth and Planetary Science Letters, 295: 321-327.

Miyamoto, M., Ohsumi, K., 1995. Micro Raman spectroscopy of olivines in L6 chondrites: evaluation of the degree of shock. Geophysical research letters, 22: 437-440.

Morlok, A., Jones, G.C., Grady, M.M., 2004. FT-IR micro-spectroscopy of fine-grained planetary materials: further results. 35th Lunar and Planetary Science Conference, abstract 1622.

Morlok, A., Köhler, M., Bowey, J.E., Grady, M.M., 2006. FTIR microspectroscopy of extraterrestrial dust grains: comparison of measurement techniques. Planetary and Space Science, 54: $599-611$

Müller, C.M., Pejcic, B., Esteban, L., Delle, P.C., Raven, M., Mizaikoff, B., 2014. Infrared attenuated total reflectance spectroscopy: an innovative strategy for analyzing mineral components in energy relevant systems. Scientific Reports, 4: 6764.

Nakamuta, Y., Motomura, Y., 1999. Sodic plagioclase thermometry of type 6 ordinary chondrites: Implications for the thermal histories of parent bodies. Meteoritics \& Planetary Science, 34: 763-772.

Nasdala, L., Smith, D.C., KaindI, R., Ziemann, M.A., 2004. Raman spectroscopy: analytical perspectives in mineralogical research. Spectroscopic Methods in Mineralogy, 6: 281-343.

Ohta, K., Iwamoto, R., 1985a. Lower limit of the thickness of the measurable surface layer on infrared absorbing substrate by FT-IR-ATR Spectroscopy. 1985 International Conference on Fourier and Computerized Infrared Spectroscopy, International Society for Optics and Photonics: 482-483.

Ohta, K., Iwamoto, R., 1985b. Experimental proof of the relation between thickness of the probed surface layer and absorbance in FT-IR/ATR spectroscopy. Applied Spectroscopy, 39 418-425.

Pilski, A.S., Przylibski, T.A., Zagożdżon, P.P., 2001. Comparative analysis of the Baszkówka and Mt. Tazerzait chondrites: genetic conclusions based on astrophysical data and the mineralogical and petrological data. Geological Quarterly, 45 (3): 331-342.

Przylibski, T.A., Pilski, A.S., Zagozdzon, P.P., Kryza, R., 2003 Petrology of the Baszkowka L5 chondrite: a record of surface-forming processes on the parent body. Meteoritics and Planetary Science, 38: 927-937.

Reach, W.T., Yesaltis, M., Rossman, G., 2012. Infrared Spetroscopy of Extraterrestrial Materials. American Astronomical Society, DPS meeting, abstract 44, id.212.04.

Rull, F., Muńoz-Espadas, M.J., Lunar, R., Martínez-Frías, J., 2010. Raman spectroscopic study of four Spanish shocked ordinary chondrites: Cańellas, Olmedilla de Alarcón, Reliegos and Olivenza. Philosophical Transactions of the Royal Society of 
London A: Mathematical, Physical and Engineering Sciences, 368: 3153-3166.

Sharp, T.G., DeCarli, P.S., 2006. Shock effects in meteorites. In: Meteorites and the Early Solar System II (eds., D.S. Lauretta and H.Y. McSween): 653-677. University of Arizona Press.

Słaby, E., Koch-Müller, M., Förster, H.-J., Wirth, R., Rhede, D., Schreiber, A., Schade, U., 2016. Determination of volatile concentrations in fluorapatite of Martian shergottite NWA. Meteoritics and Planetary Science, 51: 390-406.

Stöffler, D., Keil, K., Scott, E.R.D., 1991. Shock metamorphism of ordinary chondrites. Geochimica et Cosmochimica Acta, 55: 3845-3867.

Tyburczy, J.A., Frisch, B., Ahrens, T.J., 1986. Shock-induced volatile loss from a carbonaceous chondrite Implications for plane- tary accretion. Earth and Planetary Science Letters, 80: 201-207.

Udvardi, B., Kovács, I.J., Kónya, P., Földvári, M., Füri, J., Budai, F., Falus, G., Fancsik, T., Szabó, C., Szalai, Z., Mihály, J., 2014. Application of attenuated total reflectance Fourier transform infrared spectroscopy in the mineralogical study of a landslide area, Hungary. Sedimentary Geology, 313: 1-14.

Xie, Z., Sharp, T.G., Carli, P.S., 2006. Estimating shock pressures based on high-pressure minerals in shock-induced melt veins of $\mathrm{L}$ chondrites. Meteoritics and Planetary Science, 41: 1883-1898.

Xu, B., Poduska, K.M., 2014. Linking crystal structure with temperature-sensitive vibrational modes in calcium carbonate minerals. Physical Chemistry Chemical Physics, 16: 17634-17639. 